\title{
PERENCANAAN ARSITEKTUR APLIKASI UNIVERSITAS LAMPUNG MENGGUNAKAN ZACHMAN FRAMEWORK
}

\author{
${ }^{1}$ Ully Novianti S, ${ }^{2}$ Tristiyanto \\ ${ }^{1}$ Jurusan Ilmu Komputer FMIPA Unila \\ ${ }^{2}$ Jurusan Ilmu Komputer FMIPA Unila
}

\begin{abstract}
In the present era, to support business processes in a university requires the support of ICT in improving the quality of education and services. Analysis of the existing condition of ICT implementation in Unila using Zachman framework shows that the change in the need of application becomes the most dominant thing to be immediately corrected in various fields of work in dispersed work units. Application requirements analysis is obtained by interviewing, obervating, and giving questionnaires to internal and external customers, and conducting document study of strategic plan of Unila. The result of this research is planning of Unila application architecture in accordance with organizational purpose which can give input for management to prepare integrated application in the future.
\end{abstract}

Keywords: Zachman Framework, Application, Architecture, Unila

\section{Pendahuluan}

Perkembangan teknologi informasi dan komunikasi (TIK) sangat besar pengaruhnya pada berbagai bidang, termasuk bidang pendidikan. Perguruan tinggi sebagai salah satu contoh organisasi dalam bidang pendidikan sangat membutuhkan TIK dalam meningkatkan kualitas pendidikan dan pelayanan. Sebagai perguruan tinggi negeri di Lampung, Universitas Lampung (Unila) juga telah memanfaatkan TIK dalam menjalankan kegiatan dan aktivitasnya. Dalam rangka peningkatan pelaksanaan implementasi TIK di Unila, perlu diketahui terlebih dahulu kondisi existing implementasi TIK yang telah diterapkan. Salah satu hal yang dapat dilakukan untuk mengidentifikasi hal tersebut adalah dengan mengadaptasi suatu kerangka kerja dalam proses pengidentifikasi. Penulis mengusulkan Zachman Framework sebagai panduan dalam mengidentifikasi kondisi existing serta mengidentifikasi perubahan yang diperlukan untuk segera diperbaiki agar dapat mencapai tujuan organisasi. Zachman Framework terkenal sebagai salah satu framework yang biasa digunakan pada berbagai bidang penelitian, misalnya pada pengembangan rencana strategis sistem informasi [1], perencanaan strategis SI/TI pada perpustakaan [2], dan arsitektur pengelolaan data operasional [3]. Zachman Framework memiliki keunggulan dalam proses perencanaan yang komprehensif dalam keseluruhan enterprise, sekaligus memberikan ciri yang spesifik dari berbagai sudut pandang [4]. Hasil analisis kondisi existing Unila menggunakan Zachman framework menghasilkan suatu fakta bahwa perubahan akan kebutuhan aplikasi menjadi hal yang paling dominan untuk segera diperbaiki pada berbagai bidang pekerjaan di unit-unit kerja yang tersebar. Unila memerlukan suatu perencanaan arsitektur aplikasi dengan memperhatikan keterpaduan unit-unit organisasi dan selaras dengan tujuan organisasi.

\subsection{Arsitektur TI}

Arsitektur dapat diartikan sebagai sebuah blueprint yang menjelaskan kerjasama antara semua elemen TI dengan pihak manajemen dalam satu kesatuan dengan tujuan memberikan gambaran mengenai hubungan antara proses manajemen dengan TI yang sekarang dan yang diharapkan[5]. Arsitektur dalam konteks TI adalah dasar dari sebuah 
sistem dengan software-intensive. Sistem dengan software-intensive berarti bahwa aplikasi merupakan bagian yang paling penting dari sebuah arsitektur TI, karena dengan aplikasi maka akan memungkinkan pengguna dapat melakukan pekerjaan bisnisnya. Aplikasi akan memerlukan infrastruktur (fondasi) yang terdiri dari komputer server, desktop workstation, storage dan network. Software server termasuk middleware application server, database server, dan messaging system. Fondasi ini merupakan tempat untuk menyimpan data yang akan dioleh sebagai suatu aset dan tersedia dengan akses yang dikendalikan oleh beberapa aplikasi, sekaligus menjadi host untuk solusi integrasi agar aplikasi dapat berkomunikasi satu sama lain [6].

\subsection{Zachman Framework}

Zachman Framework (ZF) merupakan salah satu framework untuk pengembangan enterprise architecture yang diperkenalkan oleh Zachman. Kerangka kerja ini merupakan suatu alat bantu yang dikembangkan untuk memotret arsitektur organisasi dari berbagai sudut pandang dan aspek, sehingga didapatkan gambaran organisasi secara utuh [7]. ZF untuk arsitektur enterprise dapat diilustrasikan pada Gambar 1 yang terdiri dari 6 (enam) kolom dan 6 (enam) baris. Secara umum tiap kolom merepresentasikan fokus, abstraksi atau topik enterprise architecture, yaitu: What (data), How (fungsi), Where (jaringan), Who (orang), When (waktu), Why (motivasi). Keenam baris menyajikan enam pandangan (perspektif), sebagaimana yang dipandang oleh planner, owner, designer, builder, implementer dan user.

\begin{tabular}{|c|c|c|c|c|c|c|}
\hline & $\begin{array}{l}\text { What } \\
\text { (Data) }\end{array}$ & $\begin{array}{c}\text { How } \\
\text { (Function) }\end{array}$ & $\begin{array}{l}\text { Where } \\
\text { (Locations) }\end{array}$ & $\begin{array}{c}\text { Who } \\
\text { (People) }\end{array}$ & $\begin{array}{l}\text { When } \\
\text { (Time) }\end{array}$ & $\begin{array}{c}\text { Why } \\
\text { (Motivation) }\end{array}$ \\
\hline $\begin{array}{c}\begin{array}{c}\text { Scope } \\
\text { \{contextual\} }\end{array} \\
\text { Planner }\end{array}$ & $\begin{array}{l}\text { List of things } \\
\text { important to the } \\
\text { business }\end{array}$ & $\begin{array}{l}\text { List of processes } \\
\text { that the business } \\
\text { performs }\end{array}$ & $\begin{array}{l}\text { List of locations in } \\
\text { which the } \\
\text { business } \\
\text { operatses }\end{array}$ & $\begin{array}{l}\text { List of } \\
\text { organizations } \\
\text { important to the } \\
\text { business }\end{array}$ & $\begin{array}{l}\text { List of events/ } \\
\text { cycles important } \\
\text { to the business }\end{array}$ & $\begin{array}{l}\text { List of business } \\
\text { goals/strategies }\end{array}$ \\
\hline $\begin{array}{l}\text { Enterprise Model } \\
\text { \{conceptual\} } \\
\text { Business Owner }\end{array}$ & $\begin{array}{l}\text { e.g. Semantic } \\
\text { Model }\end{array}$ & $\begin{array}{l}\text { e.g. Business } \\
\text { Process Model }\end{array}$ & $\begin{array}{c}\text { e.g. Business } \\
\text { Logistics System }\end{array}$ & $\begin{array}{l}\text { e.g. Workflow } \\
\text { Model }\end{array}$ & $\begin{array}{l}\text { e.g. Master } \\
\text { Schedule }\end{array}$ & $\begin{array}{l}\text { e.g. Business } \\
\text { Plan }\end{array}$ \\
\hline $\begin{array}{l}\text { System Model } \\
\text { \{logical\} } \\
\text { Designer }\end{array}$ & $\begin{array}{l}\text { e.g. Logical Data } \\
\text { Model }\end{array}$ & $\begin{array}{l}\text { e.g. Application } \\
\text { Architecture }\end{array}$ & $\begin{array}{l}\text { e.g. Distributed } \\
\text { System } \\
\text { Architecture }\end{array}$ & $\begin{array}{l}\text { e.g. Human } \\
\text { Interface } \\
\text { Architecture }\end{array}$ & $\begin{array}{l}\text { e.g. Process } \\
\text { Structure }\end{array}$ & $\begin{array}{l}\text { e.g. Business } \\
\text { Rule Model }\end{array}$ \\
\hline $\begin{array}{l}\text { Technology Model } \\
\text { \{physical\} } \\
\text { Implementer }\end{array}$ & $\begin{array}{l}\text { e.g. Physical Data } \\
\text { Model }\end{array}$ & $\begin{array}{l}\text { e.g. System } \\
\text { Design }\end{array}$ & $\begin{array}{l}\text { e.g. Technology } \\
\text { Architecture }\end{array}$ & $\begin{array}{l}\text { e.g. Presentation } \\
\text { Architecture }\end{array}$ & $\begin{array}{l}\text { e.g. Control } \\
\text { Structure }\end{array}$ & e.g. Rule Design \\
\hline $\begin{array}{l}\text { Detailed Representation } \\
\text { \{out-of-context\} } \\
\text { Subcontractor }\end{array}$ & $\begin{array}{l}\text { e.g. Data } \\
\text { Definition }\end{array}$ & e.g. Program & $\begin{array}{l}\text { e.g. Network } \\
\text { Architecture }\end{array}$ & $\begin{array}{l}\text { e.g. Security } \\
\text { Architecture }\end{array}$ & $\begin{array}{l}\text { e.g. Timing } \\
\text { Definition }\end{array}$ & $\begin{array}{l}\text { e.g. Rule } \\
\text { Definition }\end{array}$ \\
\hline Functioning System & e.g. Data & e.g. Function & e.g. Network & e.g. Organization & e.g. Schedule & e.g. Strategy \\
\hline
\end{tabular}

Gambar 1 Zachman Framework [8]

\section{Metodologi}

Penelitian ini bersifat deskriptif kualitatif dengan tujuan untuk mendeskripsikan keadaan yang berlaku saat ini dan di dalamnya terdapat upaya mendeskripsikan, mencatat, menganalisis dan menginterpretasikan kondisi yang ada. Penelitian ini disusun melalui beberapa tahapan antara lain studi literatur, pengumpulan data, analisis data, analisis gap, perencanaan arsitektur aplikasi menggunakan Zachman Framework dan diakhiri dengan 
validasi hasil penelitian. Tahapan penelitian ditunjukkan pada Gambar 2. Selain itu, untuk dapat memahami secara lebih mudah dalam proses perencanaan, Gambar 3 menunjukkan diagram alir perencanaan arsitektur aplikasi Unila.

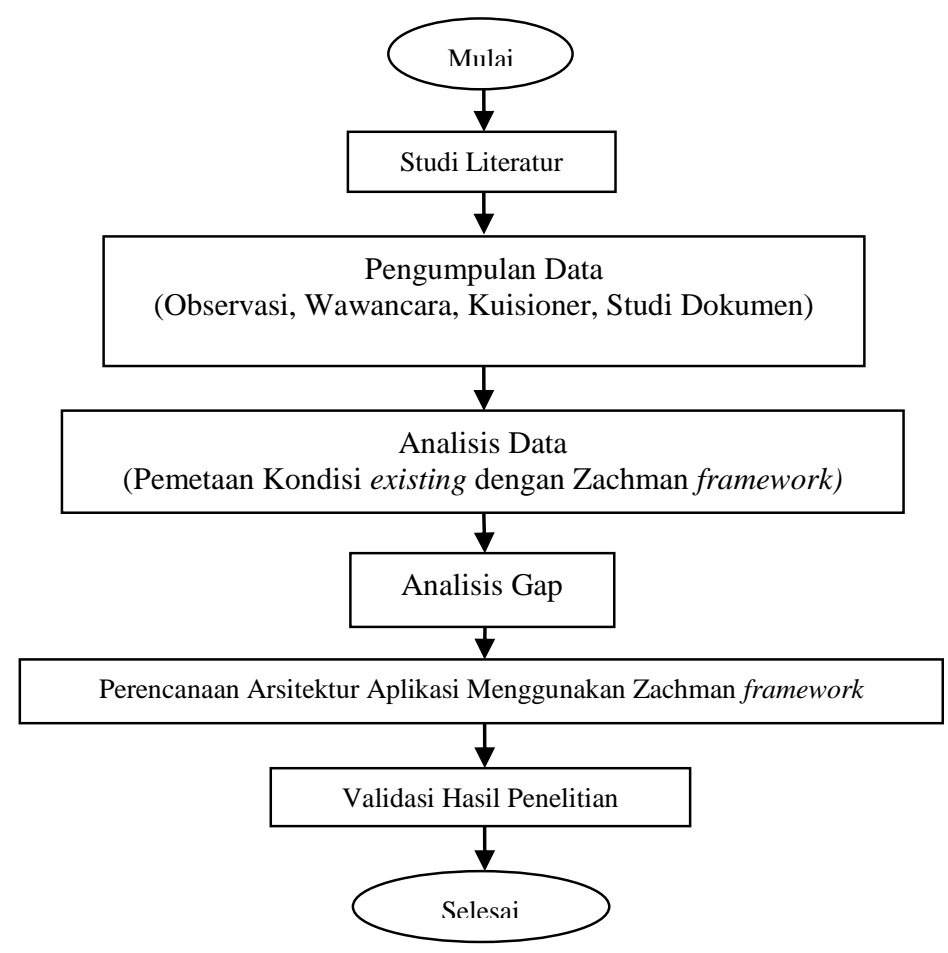

Gambar 2 Metodologi Penelitian

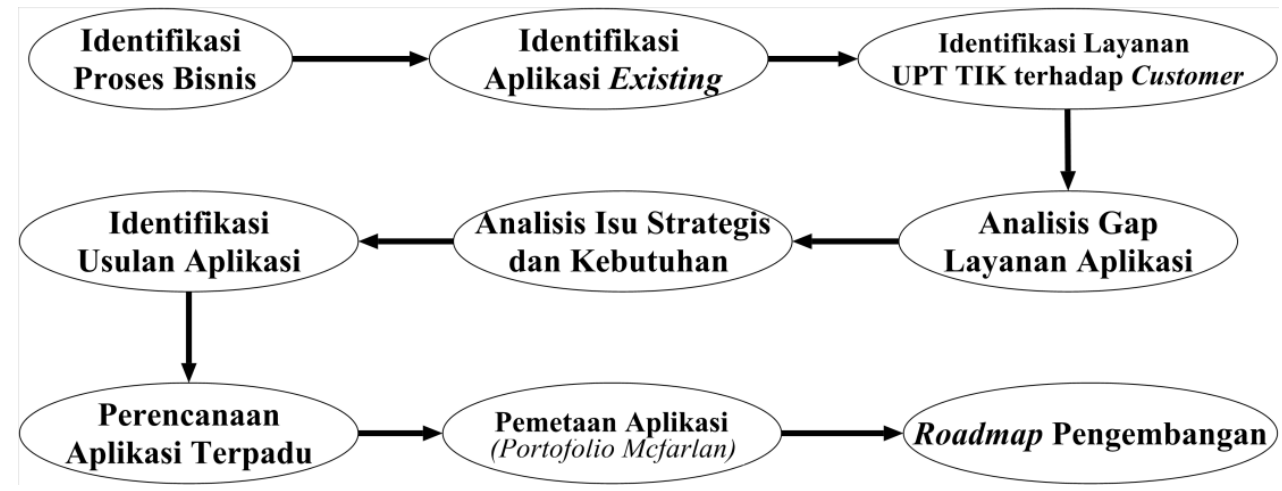

Gambar 3 Diagram Alir Perencanaan Arsitektur Aplikasi

\section{Pembahasan}

\subsection{Pemetaan Kondisi Existing pada Zachman Framework}

Sebelum memulai pembahasan, hal yang perlu dilakukan adalah memetakan data kondisi existing implementasi TIK yang telah diperoleh dari hasil pengambilan data pada tiap sel dalam Zachman Framework. Data yang diperoleh menghasilkan 14 sel yang didefinisikan antara lain pada perspektif planner dan owner pada seluruh abstraksinya, perspektif designer pada kolom how, dan perspektif builder pada kolom where. 


\subsubsection{Proses Bisnis Unila}

Rantai nilai (value chain) Porter digunakan untuk memodelkan bisnis dengan cara menganalisis dan mengidentifikasi proses bisnis utama dan proses bisnis pendukung. Terdapat 4 proses bisnis utama dan 7 proses bisnis pendukung di Universitas Lampung.

\subsubsection{Kondisi Existing Aplikasi}

Unila telah menggunakan berbagai aplikasi pada masing-masing proses bisnis yang berjalan pada masing-masing unit kerja. Gambar 4 merupakan gambaran aplikasi existing yang digunakan pada masing-masing proses bisnis menggunakan analisis value chain.

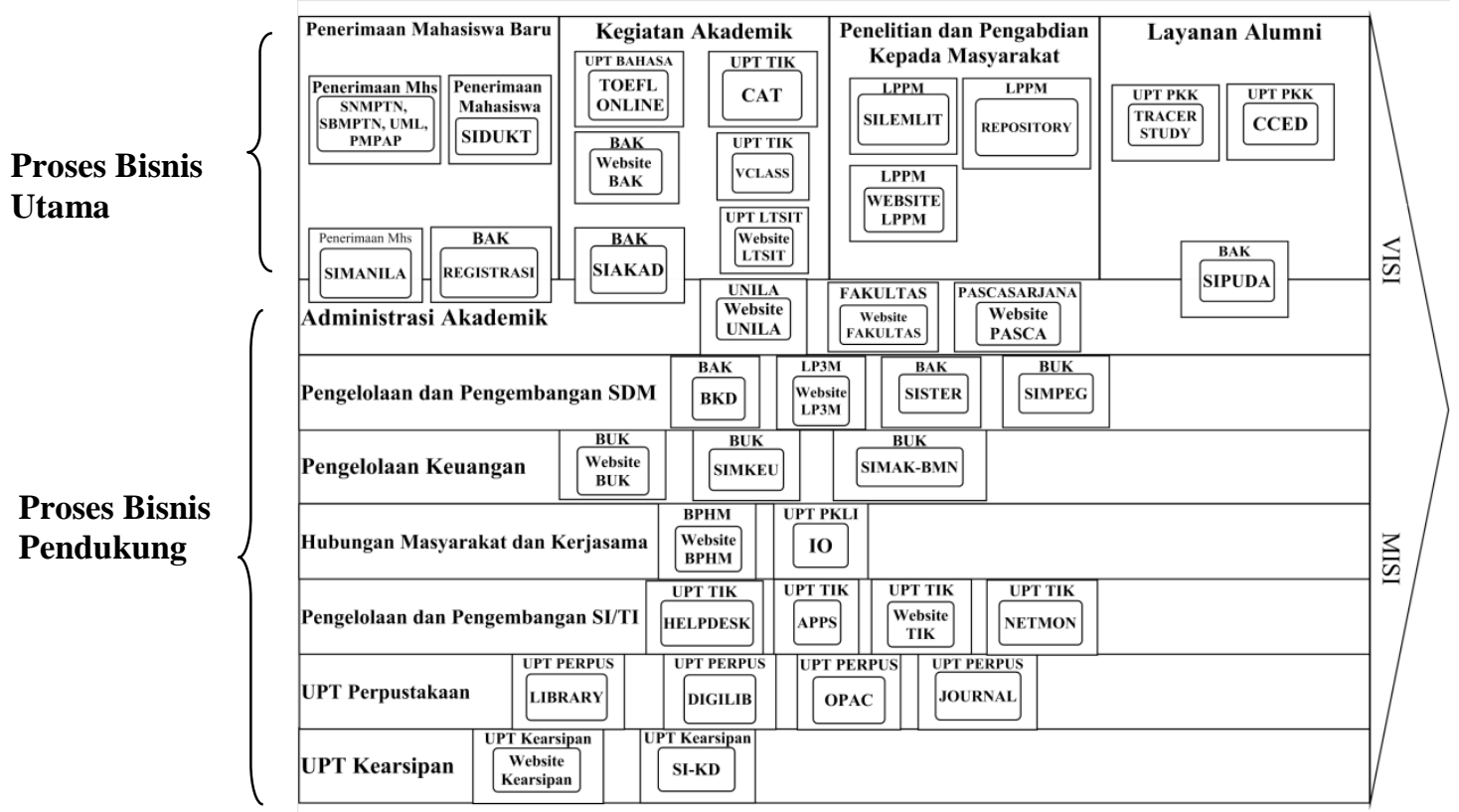

Gambar 4 Aplikasi Unila dalam Value Chain (Adaptasi dari model Porter) [9]

\subsection{Layanan UPT TIK Unila}

UPT TIK memiliki tugas melaksanakan, mengembangkan, mengelola, dan memberikan layanan TIK serta mengelola sistem informasi kepada seluruh sivitas akademika. Dalam rangka memenuhi kebutuhan aplikasi, hal yang dapat dilakukan adalah dengan mengidentifikasi customer baik dari sisi internal maupun eksternal organisasi. Hal ini dilakukan untuk memastikan bahwa seluruh customer nantinya akan mendapat layanan oleh UPT TIK. Layanan UPT TIK terhadap internal customer dan eksternal customer ditunjukkan pada Gambar 5.

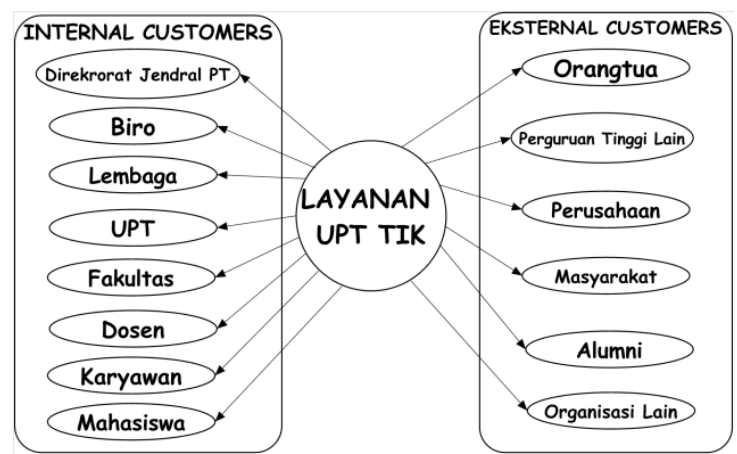

Gambar 5 Layanan UPT TIK Unila Terhadap Internal dan Eksternal Customer 


\subsection{Pemetaan Layanan Aplikasi untuk Internal customer dan Eksternal customer}

Pada Gambar 6 menunjukkan layanan aplikasi saat ini yang diberikan UPT TIK untuk internal dan eksternal customer. Dari gambar tersebut, penulis dapat lebih mudah dalam menganalisis kebutuhan para customer yang belum terlayani dengan maksimal.

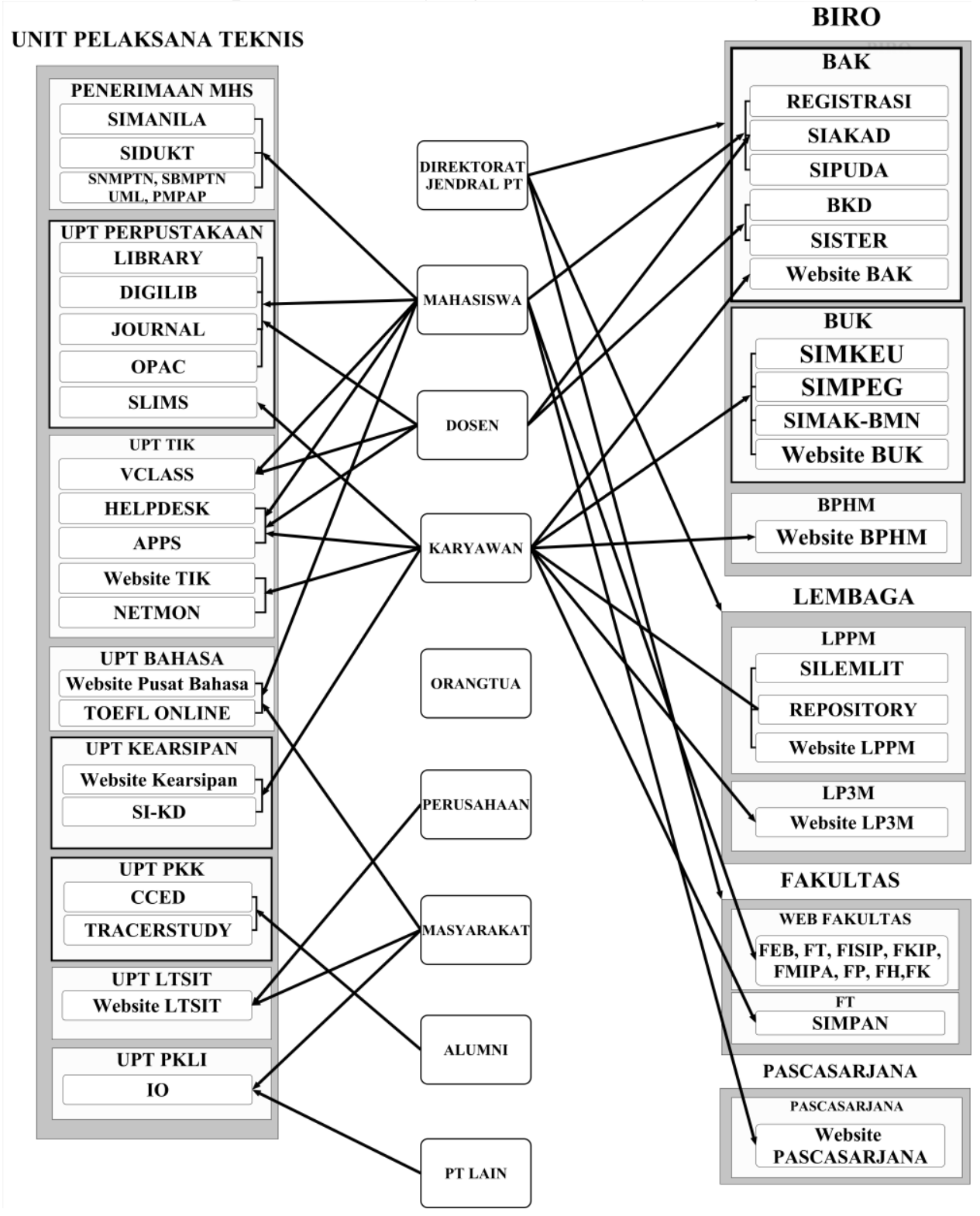

Gambar 6 Pemetaan Layanan Aplikasi untuk Internal dan Eksternal Customer

\subsection{Analisis Gap}

Analisis gap dilakukan untuk membandingkan antara kondisi existing dengan kondisi yang diharapkan serta untuk mengidentifikasi tindakan-tindakan yang perlu dilakukan. Fokus pada penelitian ini adalah menitikberatkan pada solusi aplikasi masa depan. Kemudian selain pada bagian aplikasinya, tidak dapat dipungkiri bahwa juga ditemui gap pada bidang teknologi dan sumber daya manusia. 


\subsubsection{Kesenjangan Aplikasi}

Hasil pemetaan layanan aplikasi untuk internal dan external customer menunjukkan bahwa masih ada customer yang belum mendapatkan layanan dari UPT TIK. Pihak internal maupun eksternal customer berpendapat bahwa dari aplikasi-aplikasi yang ada belum sepenuhnya memenuhi kebutuhan dari aktivitas dan kegiatan yang dilakukan.

\subsubsection{Kesenjangan Teknologi}

Menurut kepala UPT TIK, saat ini teknologi cloud computing yang diterapkan di Unila masih layak digunakan hingga 5 tahun mendatang dan bandwidth di Unila saat ini yaitu 1 Gbps telah melampaui rasio yang ditetapkan Dikti yaitu dengan rata-rata 41,71 kbps per mahasiswa. Namun, user masih menghadapi beberapa kendala yang terkait dengan kecetapan akses internet dan belum adanya fasilitas Wifi pada beberapa titik. Penambahan kapasitas bandwidth bukanlah hal yang mudah dilakukan, namun harus mempertimbangkan berbagai fungsi, manfaat terhadap tujuan utama organisasi dan tentunya dana yang dikeluarkan.

\subsubsection{Kesenjangan Sumber Daya Manusia}

Sebaran karyawan di Unila dinilai kurang merata dan sebagian besar karyawan kurang berkompeten dalam melakukan tugas dan fungsinya, khususnya pada implementasi TIK. UPT TIK juga memiliki masalah dalam bidang SDM karena jumlah karyawannya masih dalam kategori kurang memadai. Menurut kepala UPT TIK, tanggung jawab yang diemban oleh UPT TIK untuk memberikan layanan kepada seluruh unit kerja juga sebaiknya sudah dilakukan pada level lembaga. Selain itu, upaya peningkatan kualitas karyawan dan penataan dalam pendayagunaannya tentu sangat diperlukan.

\subsection{Rencana Implementasi}

Tabel 1 Rencana Implementasi

\begin{tabular}{|l|l|l|l|l|l|l|}
\hline & What & How & Where & Who & When & Why \\
\hline Planner & & & & & & \\
\hline Owner & & Update & & & & \\
\hline Designer & & Update & & & Update & Update \\
\hline Builder & & & & & & \\
\hline
\end{tabular}

Pada tahap rencana implementasi, fokus perencanaannya adalah pada bagian arsitektur aplikasinya dalam rangka memperbaiki kesenjangan yang telah diidentifikasi. Hal-hal yang akan berubah terkait dengan rencana aplikasi ditunjukkan pada Tabel 1.

1. Perspektif Owner

Kolom How: Pemodelan proses bisnis yang berjalan.

2. Perspektif Designer

a. Kolom How: Daftar kebutuhan aplikasi dari para customer beserta dengan hubungan dengan unit kerja yang akan menggunakan aplikasi.

b. Kolom When: Estimasi waktu yang diperlukan dalam mengembangkan aplikasi.

c. Kolom Why: Alasan yang menyebabkan perlunya aplikasi baru.

Beberapa isu diidentifikasi dari hasil wawancara, kuisioner dan observasi terhadap para customer untuk digunakan sebagai bahan pertimbangan dalam merencanakan aplikasi 
usulan. Terdapat 16 usulan aplikasi baru yang dihasilkan antara lain SI-Kegiatan Dosen, Sistem Surat Masuk dan Surat Keluar, Sistem Monitoring Skripsi, SI-Kenaikan Jabatan, SI-Seminar Unila, Sistem Bebas Laboratorium, SI-Layanan Administrasi Akademik, SIDokumentasi, SI-Audit, SI-Knowledge Management System, SI-Decision Support System, SI-Kerjasama, SI-Kearsipan, SI- Orangtua, Sistem Inventarisasi Laboratorium, dan SI-Alumni. Pemetaan arsitektur aplikasi usulan sesuai dengan unit kerja yang menjadi usernya ditunjukkan pada Gambar 7.

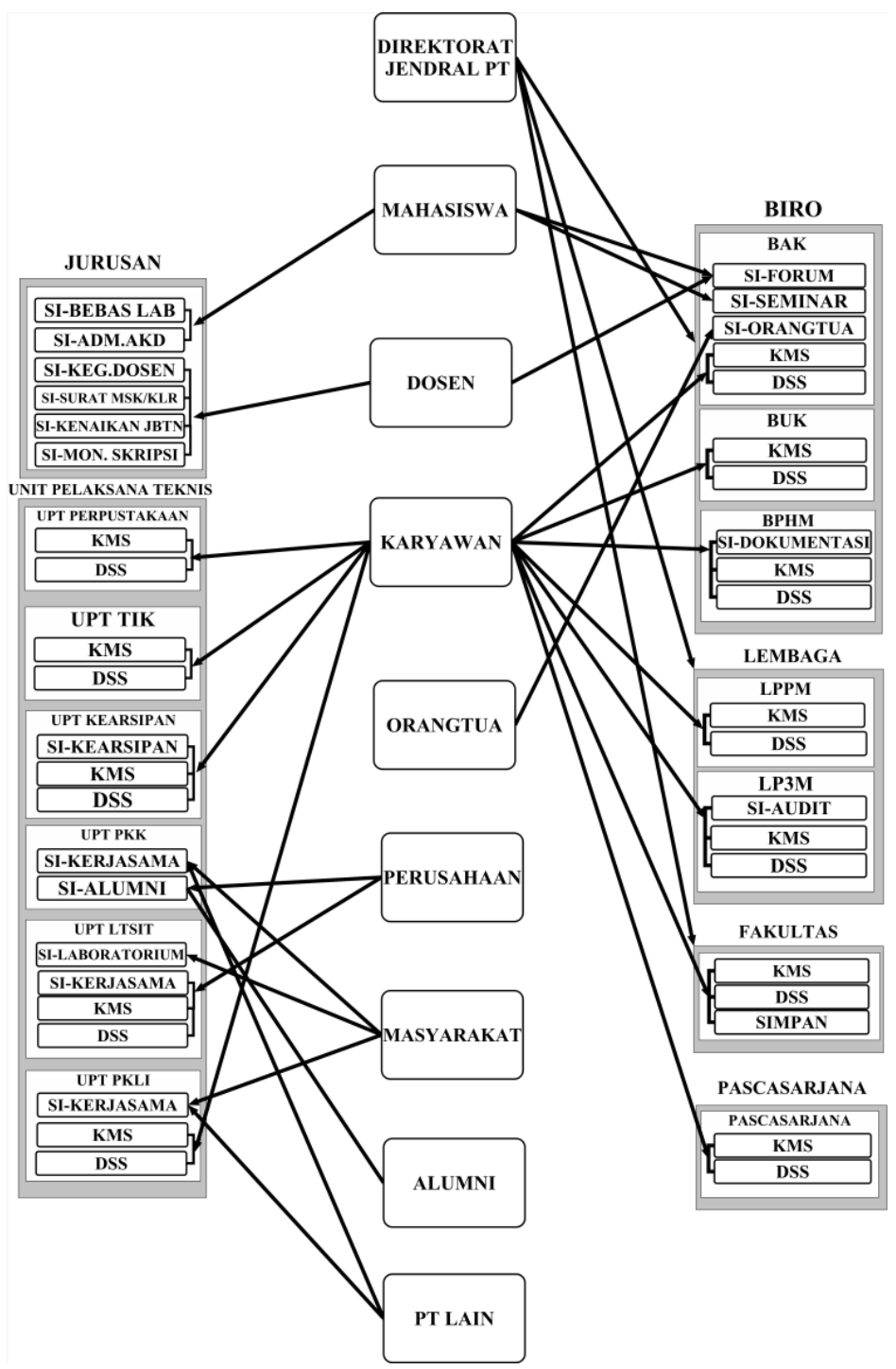

Gambar 7 Arsitektur Aplikasi Usulan Unila

Gambar 8 menunjukkan usulan aplikasi terintegrasi untuk mendukung tujuan bisnis Unila. Usulan aplikasi terintegrasi akan mengubah proses bisnis yang berjalan. Gambar 9 menunjukkan aplikasi Unila dalam value chain usulan. Kemudian, aplikasi dipetakan sesuai dengan analisis menggunakan portofolio aplikasi McFarlan untuk mengetahui kontribusi aplikasi terhadap organisasi (Tabel 2). Pada Gambar 10 menjelaskan tahapan implementasi pengembangan aplikasi yang dilakukan sesuai dengan urutan prioritasnya. Tahapan yang pertama adalah pengembangan aplikasi strategis, tahapan yang kedua 
adalah pengembangan aplikasi operasional kunci, dilanjutkan dengan pengembangan aplikasi berpotensial tinggi, dan diakhiri dengan pengembangan aplikasi pendukung.
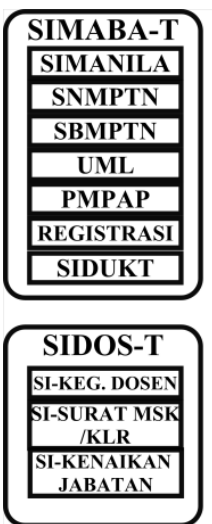
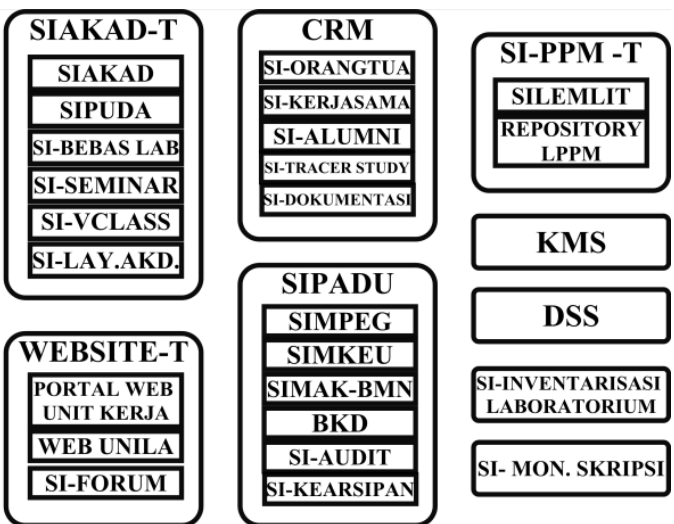

SI-INVENTARISASI

LABORATORIUM

SI- MON. SKRIPSI

Gambar 8 Usulan Aplikasi Terintegrasi Unila

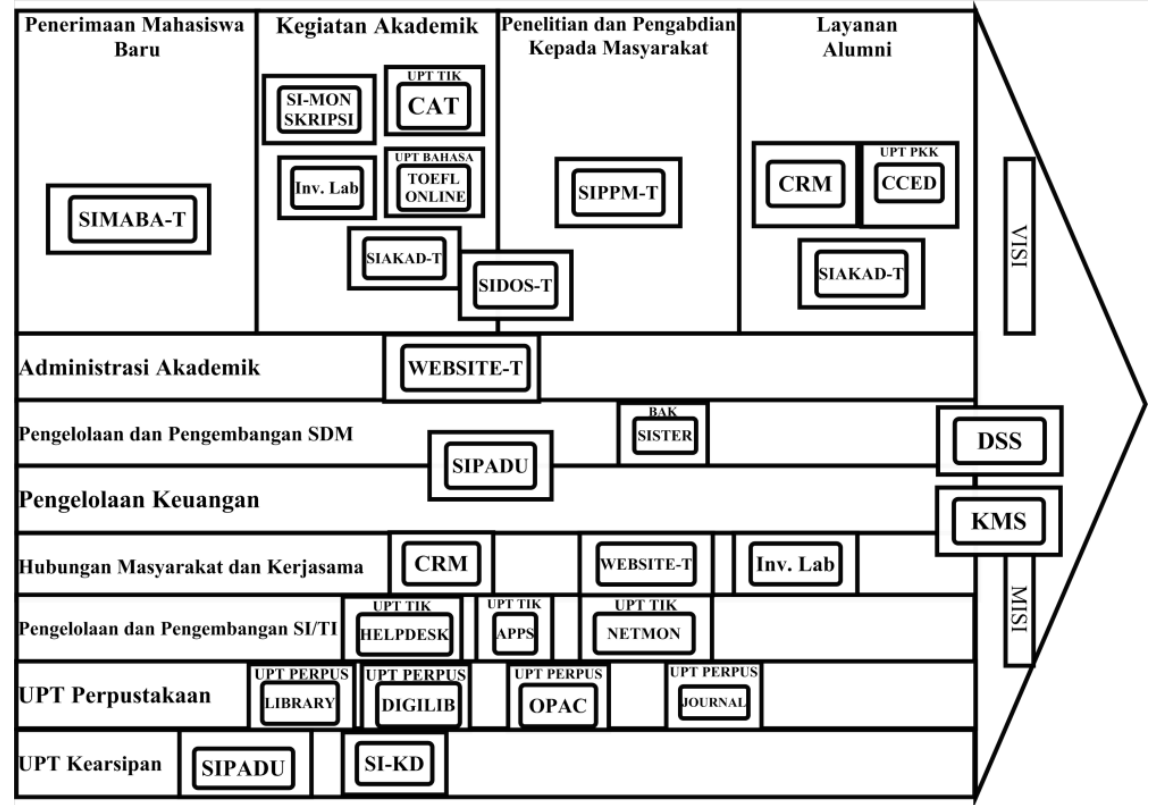

Gambar 9 Aplikasi Usulan Unila dalam Value Chain (Adaptasi dari Model Porter) [9]

Tabel 2 Portofolio Aplikasi Usulan Unila (Adaptasi dari Model Ward) [10]

\begin{tabular}{|c|c|}
\hline Strategis & Berpotensi Tinggi \\
\hline SIAKAD-T & KMS \\
DSS & SIPADU-T \\
\hline Operasional Kunci & Pendukung \\
\hline SIMABA-T & CRM \\
SIPPM-T & SI-MONITORING SKRIPSI \\
WEBSITE-T & SI-INVENTARISASI LAB \\
& SIDOS-T \\
\hline
\end{tabular}




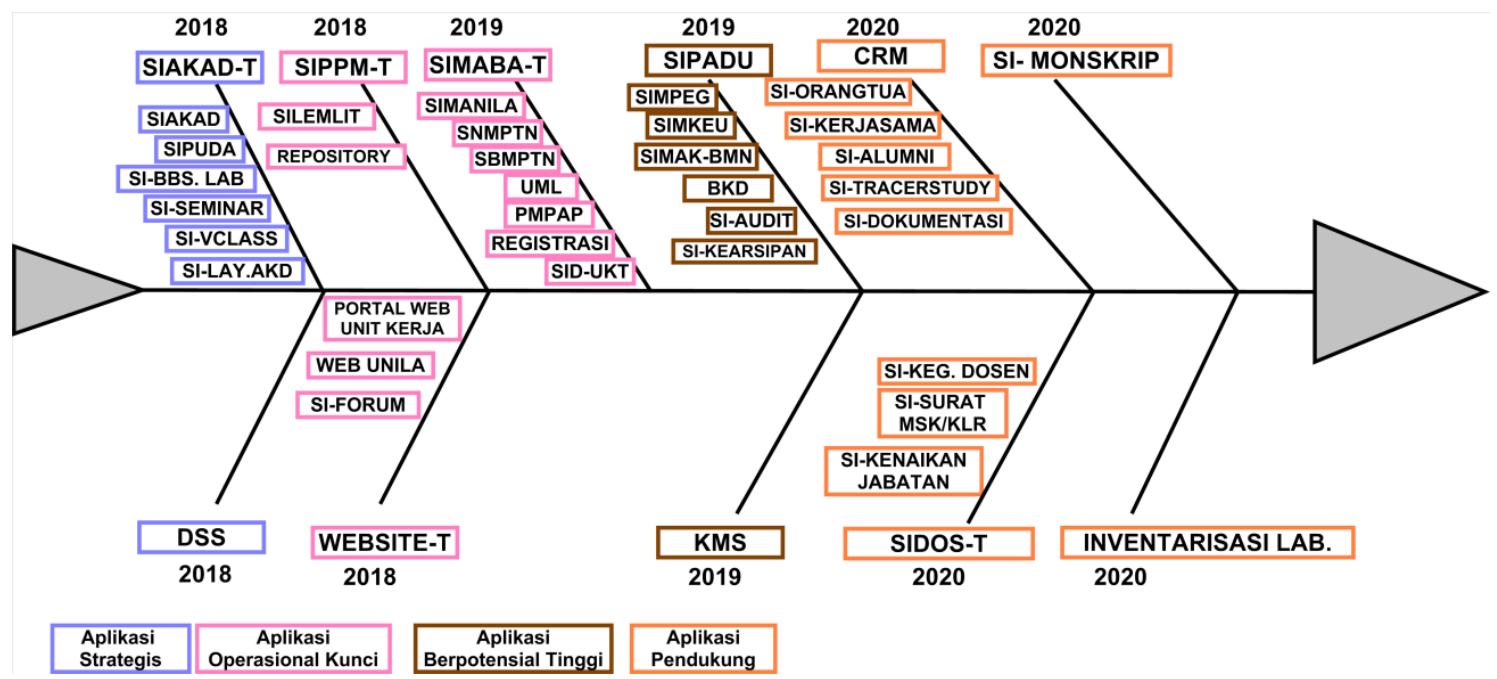

Gambar 10 Roadmap Pengembangan Aplikasi Unila (Adaptasi dari Model Ishikawa) [11]

\section{Kesimpulan}

Dari hasil penelitian dan pembahasan, penulis dapat mengambil kesimpulan sebagai berikut.

1. Pemetaan kondisi existing implementasi TIK Unila menggunakan Zachman Framework menghasilkan beberapa kendala yang ditemui pada arsitektur aplikasi saat ini yang belum cukup memenuhi kebutuhan para stakeholder hingga menghasilkan 16 usulan aplikasi baru.

2. Data aplikasi saat ini dan aplikasi usulan menghasilkan perencanaan arsitektur aplikasi dengan 11 aplikasi terintegrasi yang dipetakan menggunakan analisis portofolio McFarlan.

3. Pemetaan aplikasi masa depan menggunakan analisis portofolio McFarlan menghasilkan 2 aplikasi pada kuadran strategis, 3 aplikasi pada kuadran operasional kunci, 2 aplikasi pada kuadrah berpotensi tinggi, dan 4 aplikasi pada kuadran pendukung.

4. Teknologi cloud computing yang masih layak digunakan hingga 5 tahun mendatang.

5. Pengelolaan, perekrutan, dan pelatihan SDM TI di unit-unit kerja, khususnya di UPT TIK sangat diperlukan untuk menunjang proses bisnis.

\section{Saran}

Saran yang dapat diberikan dari hasil penelitian ini adalah sebagai berikut.

1. Perencanaan dapat dilanjutkan pada perspektif Zachman Framework selanjutnya.

2. Perencanaan aplikasi dapat diimbangi dengan sumber daya manusia yang dapat membuat, mengelola, memelihara, dan menggunakan aplikasi.

\section{Referensi}

[1] Jamaluddin., Pengembangan Rencana Strategis Sistem Informasi Menggunakan Zachman Framework dan RAISE STKIP Hamzanwani Selong, Fakultas Teknik Universitas Jogjakarta (2012).

[2] Kuntoro, Adi dkk., Perencanaan Strategis Sistem Informasi/ Teknologi Informasi Menggunakan Zachman Framework (Studi Kasus: Perpustakaan dan Arsip Daerah Kota Salatiga, Fakultas Teknologi Informasi Universitas Kristen Satya Wacana (2013). 
[3] Falahah \& Rosmala, Dewi., Penerapan Framework Zachman Pada Arsitektur Pengelolaan Data Operasional (Studi Kasus SBU Aircraft Service, PT. Dirgantara Indonesia, SNATI, Yogyakarta (2010).

[4] Sudrajat, Antonius Wahyu., Penerapan Framework Zachman Dalam Perancangan Arsitektur Sistem Manajemen Penyusunan Anggaran Keuangan Daerah (Studi Kasus UPTD Graha Teknologi Sriwijaya,. Vol 2, No 1, Hal 39-50 (2015).

[5] Lusa, S., \& Sensuse, D. I., Kajian Perkembangan dan Usulan Perancangan Enterprise Architecture Framework, Jurnal Seminar Nasional Aplikasi Teknologi Informasi 2011 (pp. G-67), SNATI, Yogyakarta (2011).

[6] Pratiwi, Vivi Fydiani., Perancangan Model Enterprise Architecture dengan Menggunakan TOGAF Architecture Development Method pada PT. Satya Karya Utama, Fakultas Sains dan Teknologi, UIN Syarif Hidayatullah (2013).

[7] Setiawan, E. B., Pemilihan EA Framework, Seminar Nasional Aplikasi Teknologi Informasi 2009 SNATI, Yogyakarta (2009).

[8] Wambler, Scott., Enterprise Unified Process (EUP): Strategies For Enterprise Agile, www.enterpriseunifiedprocess.com (15 Mei 2017).

[9] Porter, Michael E., Competitive Advantage-Creating and Sustaining Superior Performance, New York: Free Press (1985).

[10] Ward, John and Peppard, Joe., Strategic Planning for Information systems, $3^{\text {rd }}$ Edition, John Wiley \& Sons, LTD England (2002).

[11] Murnawan, Heri., Perencanaan Produktivitas Kerja Dari Hasil Evaluasi Produktivitas Dengan Metode Fishbone Di Perusahaan Percetakan Kemasan Pt.X, Jurnal Teknik Industri HEURISTIC Vol 11 No 1 (2014). 